JoHns, A. T. (1952). J. gen. Microbiol. 6, 123-127

\title{
The Mechanism of Propionic Acid Formation by Clostridium propionicum
}

\author{
By A. T. JOHNS \\ Grasslands Division, D.S.I.R., Palmerston North, New Zealand
}

\begin{abstract}
SUMMARY: Clostridium propionicum evidently possesses a mechanism for the conversion of lactate to propionate different from that found in the previously studied propionic acid producing bacteria. Reactions common to certain propionibacteria and Veillonella gazogenes which could not be demonstrated with $\mathrm{Cl}$. propionicum include: $(a)$ the decarboxylation of succinic acid; $(b)$ the fermentation of malate and fumarate; $(c)$ the variation in the ratio of acetic to propionic acid according to the concentration of $\mathrm{CO}_{2} ;(d)$ the fixation of $\mathrm{CO}_{2}$ in propionic acid.
\end{abstract}

Two mechanisms have been proposed for the formation of propionic acid from lactate by propionibacteria (Werkman \& Wood, 1942): (a) the dehydration of lactate to acrylate which is then reduced to propionate; $(b)$ the formation of succinic acid and its subsequent decarboxylation, i.e. lactate $\rightarrow$ pyruvate $\rightleftharpoons$ oxalacetate $\rightleftharpoons$ malate $\rightleftharpoons$ fumarate $\rightarrow$ succinate $\rightarrow$ propionate $+\mathrm{CO}_{2}$. The propionibacteria are unable to ferment acrylic acid, so the first mechanism is untenable for these organisms. Evidence has been presented for strains of Propionibacterium (Delwiche, 1948; Johns, $1951 \mathrm{~b}$ ) and for Veillonella gazogenes (Johns, $1951 a$ ), which indicated that $(b)$ represents the probable pathway for propionate formation in these bacteria. Cardon \& Barker (1947) have shown that $\mathrm{Cl}$. propionicum, an organism isolated from marine mud, decomposes lactate, acrylate and pyruvate to give acetic and propionic acids and carbon dioxide. The present paper gives results of experiments which attempted to demonstrate with $\mathrm{Cl}$. propionicum reactions common to propionibacteria and V. gazogenes.

\section{EXPERIMENTAL}

\section{Methods}

The methods were essentially the same as those used previously (Johns, $1951 a$ ). The Van Slyke-Folch wet oxidation as used by Barker (1949 $a$ ) was employed instead of the Pregl micro-combustion for the conversion of propionate and acetate to carbonate.

The strain of $\mathrm{Cl}$. propionicum used was isolated by the enrichment culture method (Cardon \& Barker, 1946) from a heap of decomposing grass clippings. The organism obtained readily fermented alanine, lactate, pyruvate, serine and threonine, failed to ferment sugars, and appeared in every way identical with the strain described by Cardon \& Barker (1946).

The medium used for growth and the method of preparing washed cell suspensions were those of Cardon \& Barker (1947). Cultures were harvested after $16 \mathrm{hr}$. growth at $37^{\circ}$. 


\section{RESULTS}

Succinic acid decarboxylation

Washed suspensions of $\mathrm{Cl}$. propionicum were tested by the Warburg technique for their ability to ferment succinic acid. The Warburg cups contained $1 \mathrm{ml}$. bacterial suspension (c. $20 \mathrm{mg}$. dry wt./ml.), $1.3 \mathrm{ml} . \mathrm{M} / 15$ phosphate buffer, $0 \cdot 2 \mathrm{ml} .0 \cdot 2 \mathrm{M}$ sodium succinate. The gas phase was nitrogen and the temperature of incubation $37^{\circ}$.

Over the range $\mathrm{pH} 5 \cdot 3-7 \cdot 6$ there was no change of gas pressure in the manometers. The experiment was repeated with $0.1 \mathrm{ml}$. of $0.1 \mathrm{M}$ succinate in the presence of an equimolar quantity of alanine. These combined substrates gave no greater gas production than that given by alanine alone. By the same technique it was shown that $\mathrm{DL}$-malate and fumarate, at $\mathrm{pH}$ values between $5 \cdot 0$ and $7 \cdot 6$, were not fermented by washed suspensions of the organism grown on either alanine or lactate.

\section{The effect of sodium fluoride on fermentation of lactate and pyruvate}

Barker \& Lipmann (1944), using Propionibacterium pentosaceum, found that in presence of sufficient fluoride entirely to prevent lactate reduction, pyruvic acid was reduced to propionic acid. The influence of sodium fluoride on the fermentation of lactate and pyruvate by washed suspensions of $\mathrm{Cl}$. propionicum was determined by the effect on the rate of $\mathrm{CO}_{2}$ production. The rates of both dissimilations were progressively inhibited to a similar extent by increasing concentrations of fluoride (Table 1).

\section{Table 1. Fluoride inhibition of lactate and pyruvate fermentations by Clostridium propionicum}

Manometer flasks contained $1.5 \mathrm{ml}$. of bacteria $(23 \mathrm{mg} . / \mathrm{ml}$.) in $0.1 \mathrm{M}$ phosphate buffer (pH 6.8); substrate $0.1 \mathrm{ml}$. $0.1 \mathrm{M}$ sodium pyruvate or $0.2 \mathrm{ml} .0 .1 \mathrm{M}$ sodium lactate; $\mathrm{NaF}$ as indicated; $0.2 \mathrm{ml}$. $2 \mathrm{~N}-\mathrm{H}_{2} \mathrm{SO}_{4}$; total volume $2.5 \mathrm{ml}$. Gas phase $\mathrm{N}_{2}$. Temp. $37^{\circ}$. Acid tip after $20 \mathrm{~min}$.

\begin{tabular}{ccc}
$\begin{array}{c}\text { NaF } \\
\text { concentration } \\
(1 \%)\end{array}$ & \multicolumn{2}{c}{ Percentage inhibition } \\
\cline { 2 - 2 } Lactate & Pyruvate \\
0.01 & 0 & 0 \\
0.02 & 19 & 23 \\
0.04 & 39 & 42 \\
0.10 & 76 & 80 \\
0.20 & 87 & 92 \\
& 92 & 95
\end{tabular}

Since the effect of fluoride on the fermentation of lactate and pyruvate by washed suspensions of $V$. gazogenes had not previously been determined the experiment was repeated using a washed suspension of this organism (Johns, $1951 a$ ). The gas produced in this case was hydrogen and carbon dioxide; the results are shown in Table 2. Although the fermentation of lactate is more sensitive to fluoride than is that of pyruvate, complete inhibition was not achieved even with $0 \cdot 2 \mathrm{M}-\mathrm{NaF}$. 


\section{Table 2. Fluoride inhibition of lactate and pyruvate fermentations by Veillonella gazogenes}

Manometer flasks contained $1.5 \mathrm{ml}$. of bacteria $(27 \mathrm{mg} . / \mathrm{ml}$.) in $0.1 \mathrm{M}$ phosphate buffer (pH 6.8); substrate $0.1 \mathrm{ml}$. $0.1 \mathrm{M}$ sodium pyruvate or $0.2 \mathrm{ml}$. $0.1 \mathrm{M}$ sodium lactate; NaF as indicated; $0.2 \mathrm{ml} .2 \mathrm{~N}-\mathrm{H}_{2} \mathrm{SO}_{4}$; total volume $2.5 \mathrm{ml}$. Gas phase $\mathrm{N}_{2}$. Temp. $37^{\circ}$. Tip after $10 \mathrm{~min}$.

\begin{tabular}{ccc}
$\begin{array}{c}\text { NaF } \\
\text { concentration } \\
(M)\end{array}$ & \multicolumn{2}{c}{ Percentage inhibition } \\
\cline { 2 - 3 } & Lactate & Pyruvate \\
0.0004 & 0 & 0 \\
0.002 & 0 & - \\
0.004 & 55 & - \\
0.01 & 82 & 25 \\
0.02 & 88 & 38 \\
0.1 & 90 & 44 \\
0.2 & 93 & 45
\end{tabular}

\section{Effect of $\mathrm{CO}_{2}$ concentration on fermentation of lactate}

The concentration of carbon dioxide influences the ratio of propionic to acetic acid formed by the fermentation of lactic acid by propionibacteria and by $V$. gazogenes (Johns, $1951 a, b$ ). Increased $\mathrm{CO}_{2}$ concentration produced a greater $\mathrm{CO}_{2}$ fixation leading to an increased amount of propionic acid. Similar experiments were carried out with $\mathrm{Cl}$. propionicum using three tubes of the type used by Barker $(1949 \mathrm{~b})$. Each contained $26.5 \mathrm{ml}$. of fluid made up of $25 \mathrm{ml}$. of Barker's medium ( $\mathrm{pH} 7 \cdot 18), 1 \mathrm{ml}$. sodium lactate $(0 \cdot 3 \mathrm{~g} . / \mathrm{ml}$.) and $0.5 \mathrm{ml} .1 \%$ sodium sulphide. In tube $(a)$ carbon dioxide was absorbed in alkali during incubation. In tube $(b) 1 \mathrm{ml}$. of sterile $\mathrm{N}$ sodium carbonate was added after autoclaving (the $\mathrm{pH}$ of the buffer was adjusted so that the final $\mathrm{pH}$ after addition was $7 \cdot 17$ ). This tube was gassed with sterile $\mathrm{CO}_{2}$ and sealed so that pressure increased by the amount of $\mathrm{CO}_{2}$ produced during fermentation. Tube $(c)$ was similar to $(a)$ except that the $\mathrm{pH}$ was 5.95. After inoculation the tubes were incubated for $48 \mathrm{hr}$., and the ratio of volatile acids determined chromatographically (Elsden, 1946). The ratio propionic: acetic acid was 1.96 in tube $(a), 1.93$ in tube $(b)$ and 1.95 in tube $(c)$, compared with a ratio of 2 as found by Barker (1949b). All the lactate was fermented in each case.

\section{$\mathrm{CO}_{2}$ fixation experiments}

Wood, Werkman, Hemingway \& Nier (1941) working with propionibacteria and Johns (1951 $a$ ) with $V$. gazogenes showed that during fermentation these organisms fixed $\mathrm{C}^{13} \mathrm{O}_{2}$ in the carboxyl group of the propionic acid produced. The same technique as used for $V$. gazogenes (Johns, 1951 a) was used to determine whether $\mathrm{Cl}$. propionicum could utilize $\mathrm{C}^{13} \mathrm{O}_{2}$ in the formation of propionic acid.

The medium used was as in tube $(b)$ above, with the sodium carbonate in the form of $\mathrm{Na}_{2} \mathrm{C}^{13} \mathrm{O}_{3}\left(18 \cdot 1\right.$ atoms \% excess $\left.\mathrm{C}^{13}\right)$. The complete experiment was carried out in duplicate. The mass spectrograph determinations of the $\mathrm{C}^{13}$ 
content of products which were separated chromatographically (Elsden, 1946) showed in no instance any excess of $\mathrm{C}^{13}$ over that in the control sample, indicating that there had been no fixation of carbon dioxide in either acetate or propionate.

\section{DISCUSSION}

The results indicate that $C l$. propionicum decomposes lactate to give propionic acid by a type of fermentation different from that observed with $V$. gazogenes (Johns, 1951 $a$ ) and propionibacteria (Krebs \& Eggleston, 1941; Delwiche, 1948) which ferment malate and fumarate readily and decarboxylate succinate to acid and carbon dioxide, whereas $\mathrm{Cl}$. propionicum does not. The ratio acetic: propionic acid, as determined in fermentations by propionibacteria, varies greatly according to conditions of growth. This depends mainly on the $\mathrm{CO}_{2}$ tension (Johns, 1951 b), which determines the amount of succinate formed, and on the final $\mathrm{pH}$ value of the medium, which determines the amount of succinate decarboxylated. With $\mathrm{Cl}$. propionicum variation in $\mathrm{CO}_{2}$ tension and $\mathrm{pH}$ of the medium have no effect on the acid ratio, in agreement with the observation that succinate appears not to be an intermediate in propionate formation by this bacterium.

Barker \& Lipmann (1944) found with $P$. pentosaceum that, whereas lactate decomposition was practically stopped by $0.00625 \mathrm{~m}$ fluoride, pyruvate decomposition was only $30 \%$ inhibited at this concentration; even with $0.1 \mathrm{M}$ fluoride, pyruvate was still fermented at an appreciable rate. They also found that, with lactate reduction blocked, little or no lactate accumulated when pyruvate was decomposed. This was interpreted to mean that lactate was probably not here the pathway of pyruvate reduction to propionate. With $V$. gazogenes lactate fermentation is much more sensitive to fluoride than pyruvate fermentation (Table 2). However, lactate reduction is not completely eliminated by a high concentration of fluoride. In contrast to the dissimilation of lactate and pyruvate by propionibacteria and by $V$. gazogenes, this dissimilation by $\mathrm{Cl}$. propionicum is progressively inhibited by increasing fluoride concentrations to very nearly the same degree, indicating that lactate may be on the pathway of pyruvate reduction to propionate by this organism. As shown by Cardon \& Barker (1947) Cl. propionicum ferments acrylic acid, whereas Propionibacterium pentosaceum does not (Barker \& Lipmann, 1944). The final piece of evidence for the existence of two separate mechanisms for propionic acid formation is that whereas $\mathrm{Cl}$. propionicum does not utilize $\mathrm{CO}_{2}$ for propionic acid production, propionibacteria (Werkman \& Wood, 1942) and $V$. gazogenes do (Johns, $1951 a$ ). It seems probable that the route of propionic acid formation from lactate by $\mathrm{Cl}$. propionicum is lactate $\rightarrow$ acrylate $\rightarrow$ propionate; but there is no evidence yet for the formation of acrylate during fermentation. It seems certain from the work of Carson (1948) that there is still more to be learnt about the mechanism of propionic acid formation in bacterial fermentations. He has demonstrated a conversion of acetate to propionate which is not explained by the two schemes proposed by Werkman $\&$ Wood (1942). 
My thanks are due to the Mass Spectrometry Section, A.E.R.E., Harwell, England, for carrying out the $\mathbf{C}^{13}$ analyses, and to Mr G. Page, Dominion Physical Laboratory, New Zealand, for making the arrangements with Harwell. I am indebted to Dr S. R. Elsden for reading the proofs.

\section{REFERENCES}

BARKer, H. A. (1949a). In Isotopic Carbon, p. 93. By Calvin, M., Heidelberger, C., Reid, J. C., Talbert, B. M., Yankwich, P. F. New York: John Wiley and Sons. Inc.

Barker, H. A. (1949b). In Isotopic Carbon, p. 272. By Calvin, M., Heidelberger, C., Reid, J. C., Talbert, B. M., Yankwich, P. F. New York: John Wiley and Sons Inc.

Barker, H. A. \& Lipmann, F. (1944). On lactic acid metabolism in propionic acid bacteria and the problem of oxido-reduction in the system fatty-hydroxy-keto acid. Arch. Biochem. 4, 361.

Cardon, B. P. \& Barker, H. A. (1946). Two new amino-acid fermenting bacteria, Clostridium propionicum and Diplococcus glycinophilus. J. Bact. 52, 624.

CArdon, B. P. \& Barker, H. A. (1947). Amino-acid fermentations by Clostridium propionicum and Diplococcus glycinophilus. Arch. Biochem. 12, 165.

Carson, S. F. (1948). Design and interpretation of carbon isotope experiments in bacterial metabolism. Cold Spr. Harb. Sym. quant. Biol. 13, 75.

Deswiche, E. A. (1948). The mechanism of propionic acid formation by Propionibacterium pentosaceum. J. Bact. 56, 811.

ELSDEN, S. R. (1946). The application of the silica gel partition chromatogram to the estimation of volatile fatty acids. Biochem. J. 40, 252.

Jorss, A. T. (1951 a). The mechanism of propionic acid formation by Veillonella gazogenes. J. gen. Microbiol. 5, 326.

Jorns, A. T. (1951b). The mechanism of propionic acid formation by the Propionibacteria. J. gen. Microbiol. 5, 337.

Krebs, H. A. \& Eggleston, L. B. (1941). Biological synthesis of oxalacetic acid from pyruvic acid and $\mathrm{CO}_{2}$; the mechanism of carbon dioxide fixation in propionic acid bacteria. Biochem. J. 35, 676.

Werkman, C. H. \& Wood, H. G. (1942). Heterotrophic assimilation of carbon dioxide. Advances in Enzymology, 2, 135.

Wood, H. G., Werkman, C. H., Hemingway, A. \& Nier, A. O. (1941). Heavy carbon as a tracer in heterotrophic carbon dioxide assimilation. J. biol. Chem. 139, 365.

(Received 18 July 1951) 